\title{
The Wolf, the Bear, the Master of the Winds: On the Nordic Roots of Odysseus
}

\author{
By Marco Duichin*
}

\begin{abstract}
That the early figure of Odysseus is far more ancient than the Homeric poems has already been stated by William B. Stanford's seminal monograph, "The Ulysses Theme". That the Greek hero reflects primitive shamanistic traits has also been pointed out by some prominent scholars since the first decades of the last century. In this paper, I intend to focus the attention on some singular features that can be recognized, in disguised or atavistic form, behind the character of Odysseus: an ancient and multi-layered figure springing from traditions outside the Homeric epics. More specifically, I will examine certain unexpected traits and properties that seem to place the roots of the protagonist of the "Odyssey" in a pre-Hellenic substratum of Nordic origin. This is widely suggested, among other things, by the surprising parallels that surface in the Finnish poem "Kalevala", permeated by shamanistic Lapp motifs, and is confirmed by similar evidence in the Norse sagas, in the German "Märchen", and in many Russian oral epic poems ("Byliny"), which in turn are deeply influenced by Siberian shamanism.
\end{abstract}

Keywords: Cataleptic sleep, Ecstatic combats, Limping heroes, Nordic shamanism, Odysseus' ancestry, Theriomorphism

\section{Introduction}

The fact that the early figure of Odysseus is much older than Homer and his poetic genius, was already argued, in the middle of the last century, by William B. Stanford, Regius Professor of Greek at Trinity College, Dublin (Stanford 1954: 8). Behind the multi-layered character that has come down to us under the name Odysseus/Ulysses there is the shadow of a more ancient figure springing from bardic traditions outside the Homeric epics (Thornton 1970: 22). That the Greek hero reflects primitive shamanistic traits - the roots of which lies deep in the socalled "boreal world", i.e., in the vast area of the Eurasian north running through Fennoscandia, the Baltic countries and Siberia - has been pointed out, with a variety of nuances, by many scholars of different nationalities (Bakker 2006; Baldick 2000; Burkert 1996; Carpenter 1946; Couliano 1991; Diels 1922; Duichin 2012, 2013; Greene 1996; Hatto 1980; Heubeck 1974, 1981; Lindsay 1965; Mastromattei 1988; Meuli 1935; Muster 1947; Stutley 2003; Thornton 1970; Vitebsky 2001). For evidence of this, it is enough to recall here a couple of fabulous motifs embedded in Odysseus' adventures: (a) his descent into Hades, at the northernmost reaches of the world (Od. XI: 13ff = TMI F81. Descent to lower world of dead) ${ }^{1}$, the epic transcription of an ecstatic journey into the Beyond (Burkert 1996: 68; Greene 1996; Martinotti and Chillemi 2013; Meuli 1935: 164; Muster 1947: 20; Stutley 2003: 4), that is, the main performance of the Nordic

\footnotetext{
* Member of Italian Philosophical Society, Rome, Italy.

${ }^{1}$ Northern references in Odysseus' otherworld journey: Brunel 2002: 177; Page 1983: 47; RE 18941980, Suppl. V, s.v. Laistrygonen [Meuli]: 538-539; Thornton 1970: 20-21. The Laestrygonians' country $(O d . \mathrm{X}, 80 \mathrm{ff})$ lies to the north, where the paths of day and night are close together; the sunless land of Cimmerians ( $\mathrm{Od}$. XI: 13ff), where the entrance to Hades is, was also northern.
} 
shaman; $^{2}(b)$ the profound sleep, "most closely alike unto death" (Od. XIII: 79-80 = TMI D1960. Magic sleep), so extraordinarily similar to the lethargic trance found in Lapp and Siberian shamanism, ${ }^{3}$ which seizes the hero on the ultramundane island of the Phaeacians, both on his arrival and on his departure. ${ }^{4}$

The aim of this paper is to show some surprising features that seem to place the Greek hero in a pre-Hellenic substratum of Nordic origin, as suggested by numerous parallels in the Finnish poem Kalevala, deeply permeated by Lapp shamanistic motifs (Comparetti 1891; de Anna 2001: 47; Kirkinen and Sihvo 2007: 25; Pentikäinen 1999: 177; Siikala 1986, 1999: 16), and confirmed by similar evidence in the Norse sagas, in the Germanic Märchen (Muster 1947: 58, 116) and in many Russian oral epic tales (Byliny), in turn influenced by Siberian shamanism (Meriggi 1974; Propp 1978; Vernadsky 1965). According to Apostolos N. Athanassakis $(2001,2002)$, in fact, the spread of shamanism in ancient Greece ${ }^{5}$ was related to a "northern connection", the remnants of which are reflected in the protagonist of the Odyssey, marked (unlike what usually emerges in the Iliad) by a combination of traits of a shamanistic kind.

\section{Odysseus' Ancestry: The Son of Sisyphos?}

It has long been observed that Odysseus - starting from his enigmatic name, which is certainly not Greek (Austin 2009: 92; Dimock 1956; Kamptz 1982: 355ff; Kanavou 2015: 90-105; Latacz 1990: 134; RE 1894-1980, XVII/2, s.v. Odysseus [Wüst]: 1909ff; Stanford 1952), and resists all attempts at interpretation in Indo-European terms (Lesky 1984, I: 70) - is related not only to a pre-Homeric substratum, but also to an un-Hellenic background. ${ }^{6}$ From the $1^{\text {st }}$ century B.C. to

\footnotetext{
${ }^{2}$ Muster 1947: 19: "das Haupstück aller Schamanentätigkeit [...] ist die Jenseits (Unterwelts-) Fahrt"; cf. Eliade 1964: 200ff; Meuli 1935: 172; Hultkrantz 1992: 142: "Only the shaman had the capacity to visit, in his soul, that world [the otherworld] and return again"; Thornton 1970: 23-36: "the 'scheme' of a shamanic journey is still discernible in the wanderings of Odysseus; [...] certain details may also be explicable by reference to a tradition in which shamanic material was incorporated. [...] the poet used material ultimately derived from a shaman's journey into the Beyond, [...] part of bardic tradition long before Homer".

${ }^{3}$ Olaus Magnus 1555, I: 17, 121; Schefferus 1673: XI. cf. Grambo 1973: 425: "Ecstatic sleep is the most important means of the Lappish shaman, called the noa'ide, to let his soul undertake the fearful journey to the land of the dead". The Lapp shamanism is "a western offshoot of the shamanism found among more eastern Finno-Ugrian peoples; in many respects [it is] basically similar to Siberian shamanism and generally of the same intense type as the latter" (Hultkrantz 1992: 143).

${ }^{4}$ Od. V: 491-493; VI: 1-2; VII: 283-287, 318; VIII: 445; XIII: 79-80, 92. Cf. Bakker 2006: 14; Baldick 2000: 164; Hölscher 1991: 271; Thornton 1970: 23: "Odysseus' sleep is no ordinary sleep. [...] I suggest that this sleep may be a remnant left in the story of a shaman's trance". The idea of a trance-like or death-like sleep is typical of the Nordic shamanism: Chiesa Isnardi 1991: 618-619; Eliade 1964: 59; Grambo 1973; Siikala 2007: 113-114.

${ }^{5}$ On the controversial influence of shamanism in ancient Greece: Athanassakis 2002; Bremmer 1983, 2002; Burkert 1962; Butterworth 1966; Cornford 1952; Dana 2010; Dodds 1951; Duichin 2003; Eliade 1964; Hadot 2001; Kingsley 1994; Lindsay 1965; Metzler 1982; Meuli 1935; Ogden 2004; Thornton 1970.

${ }^{6}$ Burkert 1981: 106; Hölscher 1991: 60; Lesky 1984, I: 70; Stanford 1954: 8ff. See now Renaud and Wathelet 2002: 277: "Ulysse est un héros très ancien, sûrement préhellénique, dont le nom ne peut être expliqué par le grec et qui présente des variations révélatrices d'influences
} 
the $5^{\text {th }}$ century A.D., many authors (Crates ap. Schol. in Od. X, 86; Tac. Germ. 3, 2; Aul. Gell. Noct. Att. XIV, 6, 3; Solin. XXIII, 15; Strab. III, 4, 157; Mart. Cap. 6, 629) linked the hero to the far north, pinpointing his wanderings to an area between the Baltic coasts and the Arctic Sea, with detours as far as the Atlantic shores of Lusitania. However, the question I want to ask here, taking up the intellectual challenge launched by Felice Vinci's book $\left(2008^{5}\right)$, is the following: is it possible to hypothesize a Nordic origin of Odysseus that is compatible with what the ancient sources have passed down to us (at times also hidden, disguised, or even removed) about him?

While Odysseus is indicated by Homer as the son of Laertes, ${ }^{7}$ if we are to believe an authoritative extra-Homeric tradition, Laertes would only be his putative father: instead, his true parent, according to the Greek tragedians, followed by several Latin writers, ${ }^{8}$ was Sisyphos, "son of Aiolos" (Il. VI: 154; Apd. I, 9, 3; Ovid. Met. XIII: 26). The identity of Aiolos (maybe a primordial horse-god of winds and storms of Nordic origin) ${ }^{9}$ is unclear: in fact, under this name there are various mythological characters with syncretic traits and an intricate genealogy, often overlapping the attribute of the "eponym of Aeolian people" with that of "ruler of the winds". ${ }^{10}$ To complicate things, in the late version of the mythographer Hyginus (Fab. 125), who probably was borrowed from older traditions now lost, Aiolos, son of Hellen (and thence father of Sisyphos), is identified with the Homeric Aiolos Hippotádès ("horseman's son"), ${ }^{11}$ becoming the "master" or the "king of the winds" (tamiés anémōn, rex ventorum) in Greek and Latin mythology. 12

The "very cunning Sisyphos" (Il. VI: 153) was notorious for his endless deceptions and wrong-doing. According to a scabrous alternative version to Homer, supported also by vase paintings, ${ }^{13}$ Antikleia, the daughter of Autolykos (Od. XI: 85), conceived Odysseus after having been raped by Sisyphos, or after having been seduced by fraud, on the eve of her marriage to the unaware Laertes. ${ }^{14}$ According to other versions, which might contain the misunderstood recollection

étrangères à l'usage hellénique"; Loscalzo 2012: 128: "Odysseus was not properly a Greek hero. His name [...] is proof that he was a hero known by the Achaeans only after their arrival in Greece. [...] he seems to have been transplanted into Greek culture from somewhere outside. His attributes seem to suggest that he is the result of an amalgamation of stories from diverse cultures with different economic and social systems".

${ }^{7}$ Il. III: 200-201; IX: 19; Od. IV: 555; VIII: 18; IX: 19, 531; XVI: 118-119; XXIV: 269-270.

${ }^{8}$ Aesch. fr. 175 Nauck; Soph. Philoct. 417; Aj. 190 and schol. ad loc.; Eur. Iph. Aul. 524, 1362; Cycl. 104; Lyc. Alex. 344, 1030 and schol. 344; Schol. in Il. X, 266; Ister, FGrH 3B: 183ff; Suda s.v. Sísyphos; Verg. Aen. VI: 529; Ovid. Met. XII: 31-32; Hyg. Fab. 201.

${ }^{9}$ His name has been connected with the Greek word áella, "storm" (Ferrari 1999, s.v.: 272); cf.

LSJ, s.v., 27: "stormy wind, whirlwind"; Pokorny 1959, I: 82: gr. áella "Sturm"; cymr. awel "Wind, Hauch [= blow]"; acorn. auhel "aura"; mir. ahél; aisl "Wind, Hauch". For the "horsy" lineage of Aiolos: Kerényi 1980, I: 173; II: 76.

${ }^{10}$ Hes. Cat. fr. 9 M-W; Apd. I, 7, 3; Diod. IV, 67; Plin. Nat. Hist. VII, 204. Cf. Lindsay 1965:

8; Kerényi 1980, II: 76; Grimal 1987, s.v.: 226-228; Biondetti 1997, s.v.: 233.

${ }^{11}$ Od. X: 2; Ovid. Met. XIV: 224; cf. Kerényi 1980, I: 173; Biondetti 1997, s.v. Aiolos: 234.

12 Od. X: 21; Ap. Rh. IV, 765; Verg. Aen. I: 51-63; Ovid. Met. XIV: 224; Heroid. XI: 11-15; Plin. Nat. Hist. III, 94.

${ }^{13}$ LIMC 1981-1999, I, s.v. Antikleia: Nr. 2; Kerényi 1980, II: 83.

${ }^{14}$ Cf. supra, n. 8. For this motif see Brelich 1978: 256; Carpenter 1946: 126; Hurst 2002: 123; Kerényi 1980, II: 82; Lindsay 1965: 371. 
of sexual customs practiced in the boreal area (the so-called hospitable prostitution or sexual hospitality), ${ }^{15}$ it was Autolykos himself, the night before the marriage, that offered "sharp-minded Sisyphos" (Hes. Cat. fr. $10 \mathrm{M}-\mathrm{W}$ ) his own daughter as a compliant "bedmate" (synkatéklinen) ${ }^{16}$ so that with the guest she might beget an equally cunning grandson. ${ }^{17}$

Disregarding here Robert Eisler's puzzling remark about the incestuous birth of the hero, ${ }^{18}$ Odysseus was the son of Antikleia, and grandson of Autolykos on the maternal side. Through his natural father Sisyphos he belonged to the progeny of Aiolos (Verg. Aen. VI: 529): a genealogical fact that, according to the abovementioned version of Hyginus, would link his origin to Nordic shamanism. Aiolos - well-known thanks to the Homeric episode of the "bag of winds" (Od. X: 19ff), but far less known as the possible paternal grandfather of Odysseus - betrays unexpected shamanistic powers that can be related to the ancient "weather magic", practiced from time immemorial in Finland and Lapland. ${ }^{19}$ The connection between Aiolos and the control over the winds attributed to the Finnic and Lapp magicians has long been stated by several authors. ${ }^{20}$ Furthermore, Virgil had already placed his home in a Nordic setting (Aen. I: 51-63), rather different from the usual Homeric localization. In fact, in contrast to the Odyssey (X: 1-13), Aiolos does not live in a "beautiful palace" (dōmata kalá), located on "a floating island surrounded by walls of bronze", but in a wild region violently shaken by furious winds (Nimborum patria, loca feta furentibus austris), jailed in dark caves, very similar to the stormy region described by Pliny (Nat. Hist. IV, 88), next to the cave where the north wind is born.

Georges Dumézil, on the basis of the manuscript of Närö (one of the main sources on the early religion of the Lapps), has shown the close analogies between Aiolos, "the master of the winds" of classical mythology, and Bieka-Galles, "the man of the wind" in Lapp [Sámi] tradition: an ancient divinity with shamanistic traits, characterized by two implements (an oar and a winnow) curiously echoing Teiresias's prophecy on the death of Odysseus (Od. XI: 126-135), who kept the winds imprisoned in the remote cave where he lived. ${ }^{21}$

\footnotetext{
${ }^{15}$ The custom of admitting the honoured guest to the bed of the daughter or wife was typical of the boreal peoples (Iceland, Lapland, Siberia, etc.): Blefkenius 1607: 34; Bloch 2001: 84; Bosi 1958: 287; Crawley 1902: 249; de Anna 2003; Fago 1981: 249ff; Lubbock 1879: 130-132; Ploss et al. 1935, II: 118; Schrader 1912: 93; Weber 1923: 51; Westermarck 1891: 81.

${ }^{16}$ Schol. in Soph. Aj. 190; cf. Suda s.v. Sísyphos: "Autolykos entertained him and provided his own daughter Antikleia as his bed-mate"; Schol. in Lyc. 344: Anticleam, filiam Autolyci, a patre pro furto pecorum oblatam comprimit, et ex ea Ulyssem suscipit.

${ }^{17}$ For Odysseus as trickster see now Nortwick 2009: 83-97.

${ }_{18}^{18}$ Eisler 1951: 142: "Autolykos seduces Antikleia, the daughter of the superwise Sisyphos [!]".

${ }^{19}$ Örvar-Odds saga, X, XII (= Ferrari 2003: 105, 117); Olaus Magnus 1555, III: 16, 119. According to de Anna (1996: 49; 2001: 42), the episode of Aiolos in the Odyssey seems to transpose primitive shamanistic beliefs that flourished in the Fennoscandia, and survived in the boreal peoples' customs.

${ }^{20}$ Frazer 1984, I: 129; Grimm 1888, IV: 1473; Tasso 1958, II: 270; cf. J.S. Bailly: Letter to Voltaire, 28.4.1768 (= Boitani 2016: 649).

${ }^{21}$ Dumézil 2001: 38-39; see Verg. Aen. I: 52-54; Ovid. Met. XIV: 224.
} 


\section{The Angry Grandson of Autolykos}

While the paternal ancestry of Odysseus does not win unconditional support, his maternal grandfather, unanimously attested by the sources, was Autolykos (with the sole exception, as far as I know, of the Byzantine scholar Tzetzes, who indicates him as the father of Laertes and the paternal grandfather of the hero!). ${ }^{22}$ Behind Autolykos, one can recognize the transposition of a primordial shamanhero $^{23}$ with lycomorphic traits, who has parallels in the Finnish legends (Pentikäinen 1999: 198). His therionym is a talking name, alluding to his lycanthropic nature: in fact, he is "the wolf in person" (Autó-Lykos), "the wolfman", "the werewolf of Parnassus", ${ }^{24}$ where Homer placed his inaccessible abode surrounded by windy gorges and thick forests (Od. XIX: 409ff). Son of Hermes (Hes. Cat. fr. 64 M-W; Apd. I, 9, 16; Hyg. Fab. 200), the psychagogic god connected to the realm of the dead, ${ }^{25}$ dating back to an extremely primitive civilization (Brelich 1978: 358), Autolykos had inherited shamanic powers from his divine parent: therapeutic magic, the ability to make everything invisible, the art of changing the shape and color of objects and animals as he pleased. ${ }^{26}$

In the oldest Argonautic saga (of which the Odyssey keeps a precise record), ${ }^{27}$ Autolykos was one of Jason's "helpful companions" (Apd. I, 9, 16), equivalent to the animal-spirits of Eurasiatic shamanism. They made up a strange band of therianthropic heroes (Autolykos, the wolf; Lynkeus, the lynx; Ankaios, the bear; Argos, the bull, etc.), each of which - like many heroes of Germanic and Russian fairytales ${ }^{28}$ - was endowed with a wonderful skill (e.g. sharp sight, extraordinary speed, prodigious strength), and in trance could change into the animal whose name or whose typical features he bore. ${ }^{29}$ In Homer, Autolykos plays a capital role in the paideía of Odysseus: it is in a helmet adorned with boar's tusks, stolen from his grandfather in youth, that the hero undertakes night-time expeditions at Troy (Il. X: 261ff); it is Autolykos and his sons, the maternal uncles of Odysseus, and not his putative father Laertes, that - following a pattern which finds correspondence in the Norse sagas ${ }^{30}$ - deal with the boar hunting and combat skills of the young novice (the use of weapons, wrestling, boxing) ${ }^{31}$ they are the

${ }^{22}$ Tzetz. Chil. II: 44: Autólykos, patēr dé tô̂ Laértou, páppos toû Odysséōs dé.

${ }^{23}$ Lindsay 1965: 370: "Autolykos is a thoroughly shamanist character".

${ }^{24}$ Brown 1981: 374; Burkert 1981: 106; Eisler 1951: 142; Ferrari 2002: 39; Hölscher 1991: 63; Kanavou 2015: 90; Kerényi 1980, II: 82.

${ }^{25}$ Od. XXIV: 1-14. According to Burkert (1962: 44-45) and Ogden (2004: 111), Hermes (psychagogós, psychopompós) was the divine projection of the shamanic role of the goess: he made an ecstatic journey to conduct the soul of a dead man to the underworld with magical lamentation.

${ }^{26}$ Od. XIX: 455-460; Hes. Cat. fr. 67 M-W; Schol. in Lyc. 344; Hyg. Fab. 201; Ovid. Met. XI: 313315; Tzetz. Chil. II, 44.

${ }^{27}$ Od. XII: 70. Cf. Hatto 1980: 130; Lindsay 1965: 202; Meuli 1921, 1935: 168; Page 1983: 44.

${ }^{28}$ Grimm 1980, II: No. 71, III: No. 134; Afanas'ev 2014, I: Nos. 145-147; cf. Lindsay 1965: 364365; TMI F601; AT 301B, 513, 514, 571.

${ }^{29}$ Ap. Rh. I: 151ff; Orph. Arg.: 181; Val. Flacc. I: 462; Hyg. Fab. 14. Cf. TMI F601.6. Extraordinary companions are transformed animals; Brelich 1978: 239; Duichin 2012: 63; Graf 1987: 97-98; Hölscher 1991: 171; Jochelson 1908: 47; Lindsay 1965: 89; Meuli 1921: 9; Thompson 1979: 58-59, 126.

${ }^{30}$ Völsunga saga, VI-VIII (= Meli 1997, I: 108); cf. Oitana 2005: 262.

${ }^{31}$ Graf 1987: 97. For Odysseus' skill in wrestling and bare-fisted boxing, according to the Nordic custom (Olaus Magnus 1555: V, 26, 193): Il. XXIII: 709ff; Od. VIII: 206; XVIII: 90ff; 
ones who guide him in his initiatory training amid the wild forests of Parnassus (Od. XIX: 428ff), and who treat the wound above his knee by means of a magic ritual (Od. XIX: 455-460), unknown in the Iliad, but surprisingly similar to the charm employed in the Kalevala (VIII: 133ff; IX: 267ff) by a Lapp shaman to heal the wounded knee of Väinämöinen: a ritual that recalls similar practices among North-Eurasian peoples, documented by travelers and ethnologists right up to the modern day. ${ }^{32}$

It is from Autolykos that the young Odysseus receives "splendid gifts" (aglaà $d \overline{o r a}){ }^{33}$ the actual nature of which (concealed by Homer's silence, but indirectly suggested by a parallel in Hesiod, referring to the shaman-hero Periklymenos) can perhaps be seen as a set of "gifts of magic", i.e., extraordinary powers (dōra pantôे ouk onomastá) of a shamanic kind. ${ }^{34}$ Finally, it is Autolykos that gives his newborn grandson the ambiguous name $\operatorname{Odys}(s) e u ̀ s$ (Od. XIX: 403-409), about the meaning of which scholars still wonder. This name, "grammatically obscure" (Kanavou 2015), is known to be at the center of a lasting philological dispute, which an eminent Hellenist like Albin Lesky (1984, I: 70) believed insoluble. In agreement with the most usual etymology, which derives the origin of the name from the verbal form odyssomai, in the double sense of "to be wroth against" or "to hate" (LSJ: 1199), I am inclined to accept the first hypothesis, in the active sense of "having became angry at", rather than the passive idea "having incurred the anger of". ${ }^{35}$ Odysseus would therefore be "the angry one", "the enraged", "der Zürnende": sobriquets that are well suited to the "wolfish" nature inherited from his maternal grandfather Autolykos, and that partly echo his ominous name, ${ }^{36}$ recalling the ancient Nordic belief that "a man's angry soul could manifest itself to enemies in the shape of a wolf". ${ }^{37}$

Apd. Epit. 7, 32; Hyg. Fab. 126. Cf. Duichin 2012: 70, 74 n.; 2013: 277. Also his extraordinary archery skill (Od. VIII: 215ff; XXI: 404ff) can be related to that of the Finns and Lapps, peritissimi sagittarij: Saxo 1993 V, 13, 1; Olaus Magnus 1555: IV, 11, 144-145. For the "initiatory" boar hunting of the young Odysseus: Duichin 2012: 57. Behind Autolykos and his sons one can discern an ancient werewolves-brotherhood of Parnassus (Lindsay 1965: 370371) akin to the Männerbünde widespread among Indo-European peoples (Przyluski 1940).

32 "Magic healing" is one of the "three fundamental functions" of the north-Eurasian shaman (Roux 1966: 220; cf. Eliade 1964: 215). Similar practices, attested also in Norse sources (Völsunga saga, VIII = Meli 1997, I: 109-110), were recorded by the Italian traveler Francesco Negri (1700: 43-44) among the Lapps, and by the Finnish ethnologist Mathias Alexander Castrén (Marazzi 1984: 550) among the Samoyeds of western Siberia.

${ }^{33}$ Od. XIX: 413, 460.

${ }^{34}$ Hes. Cat. fr. 33a M-W. Shamanic powers as "gifts": de Anna 2001: 47; Pentikäinen 2007b: 33

${ }^{35}$ Cf. Cesareo 1898: 80; Düntzer 1874: 105-106; Ferrari 2002: 39; George-Kokkinaki 2008: 145-146; Hölscher 1991: 62; Stanford 1952.

${ }^{36}$ Brelich 1978: 256; Kanavou 2015: 90ff; Stanford 1954: 8ff. According to Carpenter (1946: 131), if the name was originally something like Olixes/Olykios, "then Aut-olykos bestowed at least part of his name on his grandson".

37 Örvar Odds saga, V (= Ferrari 2003: 84); lyssa as "the wolves' rage": Lincoln 1975; cf. Guidorizzi 2010: 137. Some philologists have derived the form Ulixes from luk- "a wolf" (Stanford 1954: 248 n.); see also the variant Olys(s)eús [from lýssa?]. 


\section{Arkeisios, Odysseus, and the Nordic Motif of the Bear's Son}

If Odysseus' patrilineal descent from the "cursed offspring of Sisyphos" ${ }^{38}$ is related to a boreal shamanistic milieu, though accepting the more usual Laertian genealogy (Od. XVI: 118-119; XXIV: 270), there emerges in any case a Nordic background. Laertes was in fact the son of Arkeisios (Od. XVI: 118): the "bear", or, to be exact, the "bear's offspring" (árkeios = árkteios, of a bear, LSJ: 241). According to the tradition that was ascribed to Aristotle's authority (Constitution of the Ithacans, now lost; cf. Etym. M. 144, 22-32, s.v. Arkeísios; Eustath. ad Hom. Il. II, 632), Arkeisios was born from the intercourse of Kephalos with a young she-bear. ${ }^{39}$ Yet again, the ancestry of Odysseus takes us to a boreal substratum, reinforced by the polysemy of the grandfather's therionym "Arkeisios", the root of which has a twofold meaning: "bear" (árktos), and "north wind" (pnoē árkeios: Aesch. fr. 127 Nauck = a northern blast, LSJ: 241).

The descent from Arkeisios would liken Odysseus to the Nordic hero Bēowulf ("Bear's Son"), and to the berserkir ("bear-coats") of Norse poems. ${ }^{40}$ With all of these, he shares some typically ursine features: ${ }^{41}(a)$ the iron grip in wrestling, and $(b)$ the lethargic sleep, ${ }^{42}$ which, according to an Etruscan tradition preserved in Plutarch (Mor. $27 \mathrm{E}$ ), earned him in old age the singular epithet hypnōdous ("sleepy", "somnolent"). ${ }^{43}$ Think, for instance, of the wrestling skill proudly claimed by Odysseus during the Phaeacian games (Od. VIII: 206), and which he displays both at the funeral contests in honor of Patroklos (Il. XXXIII: 709ff) and during the fight with the beggar Iros at the palace of Ithaca (Od. XVIII: 1ff; Apd. Epit. 7, 32; Hyg. Fab. 126): ${ }^{44}$ probably, the outcome of the training received from his grandfather Autolykos, a real master of martial arts, who had even taught Heracles to wrestle (Apd. II, 4, 9; Herodor. FGrH, $31 \mathrm{~F} 14,17$ ). Furthermore, think of the Odysseus' cataleptic sleep in Phaeacia (the fabled equivalent of the "world of the dead"), ${ }^{45}$ so similar to that which grips Bēowulf on

\footnotetext{
${ }^{38}$ Soph. Aj. 189; Eur. Iph. Aul. 524; Lyc. Alex. 344, 1030; Ovid. Met. XIII: 31-32.

39 Stanford 1954: 248 n.; Carpenter 1946, 128: "the Parnassian trails were empty of human beings and the first female which Kephalos encountered was a she-bear. The child of this mating was Arkeisios, the Bearson, and he was the grandfather of Odysseus". For a similar story: Das Bärenkind (= Hahn 1918, II: Nos. 75, 86-88).

${ }^{40}$ Panzer 1910, I; Stitt 1992; cf. Cleasby and Vigfusson 1874, s.v.: 61; Funk and Wagnalls 1984, s.vv.: 127, 137; Lord 1965.

${ }^{41}$ Baldick 2000: 164; Carpenter 1946: 136; Hatto 1980: 123; Lindsay 1965: 369-370. Homer carefully ignores the ursine aspect of Odysseus' family.

${ }^{42}$ Carpenter 1946: 142; Hatto 1980: 123.

43 Baldick 2000: 165; Carpenter 1946: 130; Thornton 1970: 134 n. According to Agathe Thornton, "The Etruscan tradition suggests that the sleeping of Odysseus was something outside the ordinary". Cf. the "somnolent" berserkr Kveldúlfr ("Wolf of the Evening"): Dumézil 1970: 142-143.

${ }^{44}$ In Homer, Odysseus defeats Iros in a bare-fisted boxing match (Od. XIX: 90ff); Apollodorus (Epit. 7, 32) and Hyginus (Fab. 126) replace boxing with wrestling.

${ }^{45}$ George-Kokkinaki 2008: 154; Hölscher 1991: 101; Sargent 2002; Thornton 1970: 138 n.; Whittaker 1999; cf. Meuli 1935: 168: "Phäaken [sind] ursprünglich Geschöpfe einer andern Welt". According to Carpenter (1946: 150), "The whole Phaiakian episode may be a surviving representative of Bearson's visit to the underworld". The profound sleep that seizes Odysseus on the Phaeacians' land appears as a fairy-tale motif in the Nordic tradition (Grimm 1980, II:
} 
his return from Grendel's ultramundane realm (Beowulf XXV: 1792ff), or to that which, in the Kalevala (XVI: 119ff), seizes the shaman-hero Väinämöinen after his entry into the depths of Tuonela, the Finnish netherworld. ${ }^{46}$

The presence of an ursine ancestor in Odysseus' kin (Od. XIV: 182) has suggested some intriguing interpretations. ${ }^{47}$ The bear, being a totemic animal, plays a central role in the shamanistic cults and rites of northern Eurasia, especially among Siberian, Lapp and Scandinavian peoples (Basilov 1998: 51; Black 1998; Frazer 1984, II: 784; Funk and Wagnalls 1984, s.v. Bear: 124; Hallowell 1926; Pentikäinen 2007a: 24). This role often implies scabrous erotic overtones, increased by Nordic beliefs in the extraordinary sexual vigor of bears and their irresistible attraction to human females (Pentikäinen 2007a: 118-120; cf. Black 1998; Chevalier and Gheerbrant 1986, II, s.v. Orso [Bear]: 169-170; Chiesa Isnardi 1991: 578; Duichin 1996: 30; Harva 1959: 288). The embrace between a bear and a maiden - sporadically attested, as an aberration, in Greek mythology ${ }^{48}$ and in Balkan folklore $^{49}$ - occurs frequently in the Norse and Finno-Ugric traditions, ${ }^{50}$ which record ancient tales featuring a common motif: a girl meets a bear in the forest, is taken to his cave, and remains there to bring forth a son to him (Carpenter 1946: 139).

This motif figures in Saxo Grammaticus (X: 512-513) and Olaus Magnus (XVIII: 30, 627-628), and is widespread in the legends of the Ainu (Frazer 1984, II: 785-786), in the Russian folktales (Haney 2015: 65), in the mythology of Siberia $^{51}$ and of Lapland (Turi 1991: 112-113), where the intercourse of a bear with a young woman often appears as the necessary condition for transmitting shamanic powers. ${ }^{52}$ Indeed, it is an early Lapp belief that some shamans (noa'idi) are marked from birth by an odd anomaly: "a bear's paw" (Turi 1991: 113), i.e., a magic sign of their twofold nature, crossing between anthropomorphism and theriomorphism. The equivalent of this belief is also found in Caucasian tales, influenced by ancient Scythian shamanism, like the ones about the hero Bear's Ear, born of a bear and the daughter of the Avars' king, ${ }^{53}$ or about the Georgian hero Amirani, marked by a mysterious "wolf's knee". ${ }^{54}$

No. 97); it refers to the cataleptic trance that precedes the shaman's journey into the otherworld (Grambo 1973: 417).

${ }^{46}$ The Finnish expressions Tuonella käydä, Tuonelassa vaeltaa, ("to go into Tuoni", "to wander in Tuonela") refer to "journeying to Tuonela", i.e., "fall into a trance", "falling into ecstasy": Pentikäinen 1999: 179; Siikala 1999: 223.

${ }^{47}$ Funk and Wagnalls 1984, s.v. Odysseus, 813: "Odysseus himself, it has been suggested, is a Bear's Son"; cf. Carpenter 1964: 136-156.

${ }^{48}$ See the stories of Polyphonte (Ant. Lib. Met. 21) and Egesta (Serv. ad Verg. Aen. I, 550); cf. Duichin 1996: 61.

${ }^{49}$ Hahn 1918, II: Das Bärenkind. Anmerkungen, 486-487; Lindsay 1965: 369-370.

${ }^{50}$ Black 1998, 344: "Hence the multitude of stories found throughout the area where bear beliefs persist of bears inciting women to join them as lovers or wives".

${ }^{51}$ Borneman 1988, s.v. Zoofilia [Zoophilia]: 905; cf. Baldick 2000, 134: "in [Siberian] folklore bears have intercourse with women". For the "copulation of a human female with a bear", sometimes "in a dream", see Black 1998: 345.

${ }^{52}$ Pentikäinen 2007a: 119: "The coupling of bear with human is a central theme of Sámi myth, and moreover a foundation of Sámi shaman's power: they are a bear or at least of the bear's race".

${ }^{53}$ Funk and Wagnalls 1984, s.v.: 127; Hartland 1896, III: 24. In the area of distribution of bear cults, "the birth of a son is prima facie evidence of sexual copulation between a human female 


\section{Therianthropy: Wolves, Bears, Shamans, and Limping Heroes}

Like many Greek (Oedipus, Melampous, Philoctetes, Achilles et al.), and Nordic (e.g. Hadingus) characters, ${ }^{55}$ Odysseus too belongs to the number of socalled "limping heroes": a group of figures in whom a wound to the knee, the foot, the shin-bone, the heel, the thigh, or - more generally - a defect in the lower limbs, is often accompanied by shamanic powers and therianthropic traits (Duichin 1992; 2013: 281). The "shamanistic" link between therianthropy and crural defects recurs both in the Finnish hero Väinämöinen and in the Russian hero Igor'. Väinämöinen, affected like Odysseus by a youthful wound to the knee (Kalevala VIII: 158-159), was able to take the shape of an otter and a snake (Kalevala XVI: 119ff); Igor', endowed with metamorphic powers (Slovo o pülku Igoreve: 188 -191 = Saronne 1988: 154), could transform himself into an ermine, a hawk, and - above all - into a "barefoot wolf" (bosy vŭlkŭ) (Saronne 1988: 155): a rare specimen which, unlike ordinary wolves, had a "white paw", presumably, the atavistic relic of a bloody maiming. ${ }^{56}$

The seminal researches of Carlo Ginzburg (1989: 206ff) have showed the thousand-year-old link that, across a wide area of the Eurasian continent, covertly connects the crural anomaly to shamanism and lycanthropy. At times, the bloody mutilation is symbolically replaced by theriomorphic throwbacks (a bear's paw, a wolf's knee, etc.), or by identifying brands that are milder and less bloody (a scar, a tattoo, a birthmark, etc.). In any case, it is an indelible stigma, which reveals the hidden therioanthropic nature of certain individuals: according to a very archaic belief, if a lycanthrope's paw was cut off, he immediately reacquired a human shape,${ }^{57}$ but the mutilation remained on his body for the rest of his life. ${ }^{58}$

In the $5^{\text {th }}$ century B.C., Herodotus gave a strange information about the Neuri, a Scythian tribe described as a people of góetes (i.e. "shamans", according to the interpretatio graeca by Burkert 1962: 36), whose members periodically changed into wolves (Hdt. IV, 105; cf. Mel. II, 1, 14-15; Solin. XV, 2). Some centuries later, Tacitus (Germ. 46, 4) would incredulously mention the Oxiones, a Finnish tribe whose members were said to have a "human face but beastly body and limbs" (ora hominum vultusque, corpora atque artus ferarum). Tacitus relegated this belief to the many fabulous rumors about the peoples from the far north. On the

and a bear" (Black 1998: 345); but "Very exceptionally the child is born of a she-bear and begotten by a man" (Carpenter 1946: 139; cf. Panzer 1910, I).

54 Charachidzé 1988: 41-42; cf. Duichin 2012: 57-58. See also the Thracian lykopedes ("wolves-foot"): this "unexplained word is a counterpart to the Westphalian word Büksenwolf for the werewolf" (Eisler 1951: 151n.).

${ }^{55}$ Saxo Grammaticus 1993 I, VIII, 4 and 13; Olaus Magnus 1555, III: 15, 117-118; cf. Dumézil 2001: 37. For some shamanistic implications of Hadingus' limp and Odysseus' wounded knee: Duichin 2013: 281; Eliade 1964: 383; Galloni 2008-2009: 107; Ginzburg 1989: 249, 274 n.

56 Saronne 1988: 236 n.; cf. Duichin 2013: 282. See the ancient Swedish epithet guldfot ("golden foot"), having the value of a taboo-word for "wolf" (Oitana 2005: 266); similarly, in Finnish tradition the epithet Mesikäpälä ("honey paw") is a taboo-word for "bear" (Pentikäinen 2007a: 99).

${ }^{57}$ Petron. Satyr., 62; Gervasius von Tilbury, Otia imperialia, CXX, 51. Cf. Duichin 2012: 64-65 (Odysseus); Ginzburg 1989: 229.

58 Summers 1933: 206: si quid eos laedat, penetrent si vulnera quaeque, vere in corporibus semper cernuntur eorum. Cf. Lecouteux 2005: 19-20; Thompson 1979: 363; TMI D702.1.1. 
unclear identity of the Oxiones scholars were long divided, and several misleading interpretations have been given of their ethnonym (cf. de Anna 1988: 55). Tuomo Pekkanen (1983) and Juha Pentikäinen (2007a) had the merit of showing that "Oxiones" is a self-referential name, deriving from the Finnish oksi: one of the most archaic words (cognate with the Livonian okś, and still used in Finland as one of the alternative terms other than the more common karhu) used by protoFinnic peoples to call the bear. The mysterious Oxiones were, in few words, simply the clan of the "Bears", once living between Finland and Russian Karelia (Pekkanen 1983: 50). The passage from Tacitus records a confused memory of shamanistic rites practiced of old by Finns and Lapps, and surviving until recent times among some ethnic groups in Siberia (Pentikäinen 2007a: 23). So, the fabulous Oxiones of semi-beastly appearance had their roots in ancient ecstatic rituals, during which, wrapped in bearskins, ${ }^{59}$ the clan members were magically "transformed" into the totemic animal whose name they bore ${ }^{60}$ Both in Herodotus and in Tacitus, individuals belonging to ancient peoples living in northern Eurasia were credited with the power to periodically assume, in a state of trance, the shape of wolves and bears: the same animals that the classical mythology regarded as the ancestors of Odysseus, personifying them in two therianthropic heroes (Autolykos and Arkeisios).

The reports by the ancient historians helped to increase for centuries the most varied legends about the "lycanthropy" of boreal peoples, without their shamanistic implications being understood. The discovery (or rather, the "rediscovery") of Nordic shamanism by Western culture dates back to a relatively recent age, between the end of the $17^{\text {th }}$ and the beginning of the $18^{\text {th }}$ centuries (Bremmer 2002: 27-28; Flaherty 1992; Ginzburg 2006; Roux 1961). It was in those years, for instance, that the Italian traveler Francesco Negri, the first one to reach the North Cape, described the Lapps' alleged ability to change into bears and wolves, interpreting this "natural affliction called Lycanthropy by physicians" as a type of "temporary madness" (pazzia temporanea) (Negri 1700: 44).

At the beginning of the $20^{\text {th }}$ century, the Norwegian scholar Just K. Qvigstad published a strange account about the Skolt Sámi, a Lapp tribe with shamanistic customs, living in northern Finland: the young males, according to local informers, could transform themselves at will into bears and wolves (Qvigstad 1927, III/1: 403-407). The unusual fact was the singular behavior of the clan, when faced with a such metamorphosis: instead of causing fear or shock, it was viewed favorably by the parents of the pretended "lycanthropes", who thought it better for their children to run around as wild beasts than to be recruited as soldiers in the service of the king of Sweden. ${ }^{61}$ Now, it is quite reasonable to suppose that in order to

\footnotetext{
${ }^{59}$ Eliade 1964: 459: "For primitive man, donning the skin of an animal was becoming that animal, feeling himself transformed into an animal".

${ }^{60}$ de Anna 1988: 57-58; Pentikäinen 1999: 198; cf. Dasent 1903, CXVII: "Finn and Lapps, who from time immemorial have passed for the most skilful witches and wizards in the world, can at will assume the shape of bears". Similar practices among the Nenets (Samoyeds) of Siberia: Basilov 1998: 33.

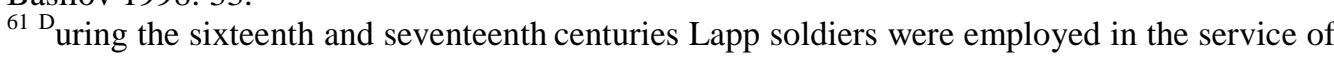
the Swedish army; Lapps were particularly feared by the enemy since they were believed to have extraordinary powers connected to their fame as sorcerers: de Anna 1996: 62-63; Pentikäinen 2007a: 43-44.
} 
escape from military conscription, the young males simulated (as Negri had already guessed) a temporary madness, during which, in a trance-like state, they imitated the behavior and the cries of bears and wolves, their totemic animals: not by chance, the Skolt Sámi were regarded by the surrounding tribes as "a cunning people" (Qvigstad 1927, III/1: 407; Pentikäinen 2007a: 110).

These primitive beliefs may arouse a smile, but it must be remembered that also the cunning Odysseus, "master of every trick" (Od. IX: 19-20), descended on the maternal side from a lycanthropic ancestor (Eisler 1951: 142), and on the paternal side from an ursine kin (Carpenter 1946: 127; Lindsay 1965: 369-370), resorts to a similar trick, feigning momentary madness "in order to avoid conscription" (Hurst 2002: 123; Stanford 1954: 82). The story was known to Homer, who however makes only a cursory reference to it (Od. XXIV: 115-119). Fleetingly echoed by later sources (Schol. in Lyc. 818; Apd. Epit. 3, 6-7; Ovid. Met. XIII: 57), and described in more detail by Hyginus (Fab. 95), the hero's madness was the leitmotif of the Odysseús mainómenos, a lost tragedy by Sophocles "about his attempt to avoid fighting at Troy by pretending to be insane" (Thorburn 2005: 374). Unfortunately, precious clues to the symptomatology of Odysseus' insanity have been lost forever. However - thanks to the tidings about the "lycanthropic" behavior of many Greek heroes (Orestes, Heracles, Ajax, Dolon), who, in the grip of delirium, "changed their shape" and "bellowed like bulls, and howled like dogs", or assumed a lycomorphic semblance to escape their enemies $^{62}$ - we can reasonably image the modus operandi of the cunning Odysseus, inherited from his natural father Sisyphos (the trickster), and from his grandfathers Arkeisios (the bear) and Autolykos (the wolf). ${ }^{63}$

So, it is no coincidence that some modern scholars have recognized in Odysseus (Burkert 1981: 106), Dolon (Gernet 1981: 125), and Orestes (Devereux 1978: 62), the disguised traits of the "werewolf". Moreover, physicians in lateAntiquity (Galenus, Oribasius, Aetius, Marcellus of Side) had a good knowledge of a psychotic syndrome called kynánthrōpos nósos, kynanthropía, lykanthropía, furor lupinus, morbus lupinus, and insania lupina, which made some men temporarily similar to wolves and rabid dogs (Buxton 1987; Eisler 1951; Roscher 1896); to the momentary symptoms manifested during periodic crises, Galenus (De atra bile, 3 ) added the presence of a permanent anomaly characterizing the socalled lycanthropes, mysteriously afflicted by incurable wounds to the legs (tibias exulceratas insanabiles).

\section{Shamanistic Metamorphoses and Ecstatic Combats}

In the Greek mythology, "shamanistic" figures like Proteus and Periklymenos, but also the Telchines (spiteful sorcerers and góêtes), similar to the goblins and kobolds of Nordic legends (Rose 1964: 167), can assume the most varied of forms:

${ }^{62}$ Eur. Iph. Taur. 281-295; Herc. fur. 867-869; Soph. Aj. 317-322; Ps-Eur. Rh. 208-215 (cf. Il. $\mathrm{X}$ : 334). For the Orestes' crisis as a form of lycanthropy "of a specifically Greek type": Devereux 1978: 62; it shows a striking similarity both to the delirium of Heracles (Guidorizzi 2010: 165-166) and to the shamanic trance of the Finnish tietäjä (Siikala 2007: 107-113).

${ }^{63}$ Some ancient northern peoples (e.g. the Celts) believed that "Lycanthropy ran in families" (Eisler 1951: 138). 
lion, boar, panther, bull, snake, eagle, and even bee, fly or ant, ${ }^{64}$ the very same animals and insects into which the Finnish and Russian epic heroes are transformed in trance, when they need to escape from danger, enter inaccessible places, or fight threatening opponents. ${ }^{65}$

The ecstatic combat between two theriomorphic shamans is an extremely archaic motif, shared by Finno-Ugric and Palaeoasiatic peoples in the boreal regions, whose origins are believed to date as far back as the Neolithic age (Diószegi 1952; Tolley 1994). During the ecstatic trance that accompanies the fight, the soul of the Nordic shaman usually takes the form of a reindeer (or at times of an elk, a seal or a whale), but it is not unusual to find metamorphoses into wild beasts (bear, wolf, boar), and birds of prey (eagle, hawk, horn owl) (Athanassakis 2002: 52; Diószegi 1952; Eliade 1964: 89; MacCulloch 1905: 161; Pentikäinen 1999: 197-198; Siikala 2007: 137ff; Waida 1983: 232ff). The Russian oral poems (Byliny), deeply influenced by Siberian shamanism, retain many traces of lycomorphic and ornithomorphic transformations, often together (Saronne and Danil'čenko 1997). In the bylina of Vol'ga, for instance, the hero can assume many shapes, including that of a "wolf" [171] and a "horn owl" [75]; in another ancient bylina, Volch changes into "grey wolf" [47], and into "flashing hawk" that "flies afar on the azure sea, destroying geese and white swans" [80-82]. In the Poem of Igor', Bojan changes into a "grey wolf on land and ash-colored eagle under the clouds", launching "ten hawks on a flock of swans" [3-4]; prince Vseslav "runs the night in the form of a wolf" [155-159], and the bogatýr Igor', besides changing into a "barefoot wolf", flies "under the haze in the shape of a hawk, killing geese and swans" [189-190]. Similarly, in the Finnish shamanistic runes, Väinämöinen too destroys "a flock of swans and a gaggle of geese" (Kalevala XVI: 132-133); the shaman-hero Lemminkäinen "travels to Pohjola in the form of a wolf" (Lemminkäinen's Rune = Pentikäinen 1999: 199), and, in order to get his bride, he must shoot "the swan of Tuoni raising a single arrow" (Kalevala XIV: 373-382).

The shamanistic motif of combat in the form of birds of prey is not only confined to the Finnish and Russian epics, but also appears in the Icelandic (Ellis 1968: 126, Siikala 2007: 139) and Celtic sagas (Agrati and Magini 1982: 110112). Furthermore, it is not unknown to classical mythology, where the hero Periklymenos, to whom Poseidon granted the shamanic power to change during combat into whatever he wanted, is oftentimes depicted as an eagle. ${ }^{66}$ In the version of his death handed down by Ovid (Met. XII: 560-561), it is in the shape of an eagle that Periklymenos engages in a fatal duel with Heracles, behind which there emerge semi-cancelled relics of an ecstatic fight between shamans. ${ }^{67}$

\footnotetext{
${ }^{64}$ Proteus: Od. IV: 349ff; Diod. I, 62; Nonn. Dionys. I: 14ff; Ovid. Met. VIII: 731ff; Verg. Georg. IV: 406; Tzetz. Chil. II, 12; Athanassakis 2002. Periklymenos: Hes. Cat. frr. 33b, 43 M-W; Apd. I, 9, 9; II, 7, 3; Ap. Rh. I: 156-160 and schol. 156; Ovid. Met. XII: 556ff; Schol. in Od. XI, 289; Eustath. ad Hom. Od. XI, 285; Duichin 2013: 288. Telchines: Diod. V, 55; Grimal 1987, s.v.: 640; Lindsay 1965: 195.

${ }^{65}$ Kalevala XVI: 189ff; Pentikäinen 1999: 206; Saronne 1988: 59, 145, 155; Saronne and Danil'čenko 1997: 107, 113, 121-125.

${ }^{66}$ Hes. Cat. 15, fr. 33b M-W; Ovid. Met. XII: 556ff; Hyg. Fab. 10.

${ }^{67}$ Burkert 1979: 86. According to other versions (Eustath. ad Hom. Od. XII, 285; Schol. in Il. II, 236; Apd. I, 9, 9), Periklymenos is killed after taking the form of a fly or a bee. See also the
} 


\section{Conclusion}

Dreaming of an eagle is a typical experience in Finno-Ugric shamanism, in which this totemic bird often constitutes the chosen form that the shaman takes during a trance to fight opponents in the semblance of geese or swans (Corradi Musi 2004: 61; Eliade 1964: 71; Roux 1990: 169). A striking parallel recurs in the Odyssey (XIX: 535ff), where Odysseus appears in a dream to Penelope in the shape of an eagle (aietòs órnis) exterminating a gaggle of geese. It is a "shamanic" dream, symbolizing the demise of the Suitors, the hero's arrogant enemies destined to fall under the arrows of his infallible bow (Mastromattei 1988), already foreseen by Teiresias ( $O d$. XI: 115ff). It is worth summing up: swooping down from a mountain, a majestic eagle breaks the necks of twenty geese that are pecking at wheat at Penelope's home, killing them all; ${ }^{68}$ then, the eagle soared off into the sky, and he came back again, perching on the roof of the palace; from there, he speaks to Penelope with a human voice, revealing his secret identity and, at the same time, the latent content of the dream: "Before I was an eagle, / and now again come back as thy husband, / and to all the suitors I will bring a shameful death" (Od. XIX: 548-550).

Now, in the light of similar episodes that have many Nordic heroes as protagonists, the strange aquiline metamorphosis of Odysseus discloses an unexpected meaning (often neglected or misunderstood by scholars), ${ }^{69}$ which seems to retain traces of a shared shamanistic substratum, strengthening the hypothesis of a hidden link between the Homeric Odyssey and the ancient epics of northern Eurasia.

\section{References $^{70}$}

Aarne A, Thompson S (= AT) (1961) The Types of the Folktale: A Classification and Bibliography. FF Communications 75(184). Helsinki: Academia Scientiarum Fennica.

Afanas'ev AN (2014) The Complete Folktales of A.N. Afanas'ev: Vol. I, edited by JV Haney. Jackson, MS: University Press of Mississipi.

Agrati G, Magini ML (1982) La saga irlandese di Cu Chulainn (The Irish Saga of Cú Chulainn), edited by G Agrati, ML Magini. Milan: Mondadori.

mortal combat between Heracles, the shamanic "Master of animals" (Burkert 1979), and Kyknos ("the Swan"): Hes. Scut. 57ff; Plut. Tes. 11; Apd. II, 7, 7; Hyg. Fab. 31.

${ }^{68}$ For a Lapp parallel: Siikala 2007: 135. Curiously, also the Celtic hero Cú Chulainn, endowed with shamanic powers, kills a flock of twenty swans (Agrati and Magini 1982: 28).

${ }^{69}$ Harsh 1950; Hölscher 1991: 274; RE 1894-1980, Suppl. VII, s.v. Odyssee [von der Mühll]: 750; Rozokoki 2001; Schwartz 1924: 110; Wilamowitz-Moellendorf 1927: 87; Woodhouse 1930: 88; see now Duichin 2013: 289-290. Among the few who sensed the hidden shamanistic connotation of the episode, cf. Weicker (1902: 22), according to whom the eagle was the soul of Odysseus which "mysteriously left his body during the spirits' hour".

${ }^{70}$ For the sake of brevity, the bibliographic references do not include, except for the Homeric poems (Iliad [1951], Odyssey [1968]), the Greek and Latin sources, quoted in the text according to the usual standard abbreviations. 
Athanassakis AN (2001) Shamanism and Amber in Greece: The Northern Connection. In J Pentikäinen (Ed.), Shamanhood: Symbolism and Epic (203-220). Budapest: Akadémiai Kiadó.

Athanassakis AN (2002) Proteus, the Old Man of the Sea: Homeric Merman or Shaman? In A Hurst, F Létoublon (Eds.), La mythologie et l'Odyssée. Hommage à Gabriel Germain (Mythology and the Odyssey. Tribute to Gabriel Germain) (45-56). Genève: Droz.

Austin N (2009) Name Magic in the Odyssey. In LE Doherty (Eds.), Homer's Odyssey (91-110). Oxford: Oxford University Press.

Bakker EJ (2006) Homeric Epic Between Feasting and Fasting. In F Montanari, A Rengakos (Eds.), La poésie épique grecque: métamorphoses d'un genre littéraire (Greek Epic Poetry: Metamorphoses of a Literary Genre) (1-39). VandœuvresGèneve: Fondation Hardt.

Baldick J (2000) Animal and Shaman: Ancient Religions of Central Asia. New York: New York University Press.

Basilov VN (1998), Scelti dagli spiriti (Chosen by the Spirits). In MM Balzer (Eds.), I mondi degli sciamani (The Worlds of the Shamans) (5-62). Milan: Gallone Editore.

Beowulf (1987) Beowulf ( $8^{\text {th }}$ cent.), edited by L Koch. Turin: Einaudi.

Biondetti L (1997) Dizionario di mitologia classica (Dictionary of Classical Mythology). Milan: Baldini \& Castoldi.

Black LT (1998) Bear in Human Imagination and Ritual. Ursus 10: 343-347.

Blefkenius D (1607) Islandia, sive populorum \& mirabilium quae in ea insula reperiuntur accuratior descriptio (Iceland, or a Very Precise Description of the Peoples and Wonders which Can Be Found in That Island). Ludguni Batavorum: Haestens.

Bloch I (2001) Anthropological Studies on the Strange Sexual Practices of All Races and All Ages. Honolulu, HI: University Press of Pacific.

Boitani P (2016) Il Grande racconto di Ulisse (The Great Story of Ulysses). Bologna: il Mulino.

Bornemann E (1988) Dizionario dell'erotismo (Lexicon of Love and Sexuality). Milan: Rizzoli.

Bosi R (1958) Dizionario di etnologia (Dictionary of Ethnology). Milan: Mondadori.

Brelich A (1978) Gli eroi greci. Un problema storico-religioso (The Greek Heroes. A Historical-Religious Problem). Rome: Edizioni dell'Ateneo \& Bizzarri.

Bremmer JN (1983) The Early Greek Concept of the Soul. Princeton, NJ: Princeton University Press.

Bremmer JN (2002) The Rise and Fall of the Afterlife. London, New York: Routledge.

Brown JP (1981) The Mediterranean Seer and Shamanism. Zeitschrift für die Alttestamentliche Wissenschaft 93(3): 374-400.

Brunel P (2002) Le pays des Cimmériens (The Land of Cimmerians). In A Hurst, F Létoublon (Eds.), La mythologie et l'Odyssée. Hommage à Gabriel Germain (Mythology and the Odyssey. Tribute to Gabriel Germain) (169-190). Genève: Droz.

Burkert W (1962) ГОН $\Sigma$. Zum griechischen "Schamanismus" ( $\Gamma \mathrm{OH} \Sigma$. On Greek "Shamanism"). Rheinisches Museum 105(1): 36-55.

Burkert W (1979) Heracles and the Master of Animals. In Structure and History in Greek Mythology and Ritual (78-98). Berkeley, Los Angeles: University of California Press.

Burkert W (1981) Homo Necans. Antropologia del sacrificio cruento nella Grecia antica (Homo Necans: The Anthropology of Ancient Greek Sacrificial Ritual and Myth). Turin: Boringhieri.

Burkert W (1996) Creation of the Sacred: Tracks of Biology in Early Religions. Cambridge, MS: Harvard University Press. 
Butterworth EAS (1966) Some Traces of the Pre-Olympian World in Greek Literature and Myth. Berlin: de Gruyter.

Buxton R (1987) Wolves and Werewolves in Greek Thought. In J Bremmer (Eds.) Interpretations of Greek Mythology (60-79). London: Routledge.

Carpenter R (1946) Folk Tale, Fiction, and Saga in the Homeric Poems. Berkeley, Los Angeles: University of California Press.

Cesareo P (1898) L'evoluzione storica del carattere di Ulisse (The Historical Evolution of Ulysse's Character). Rivista di storia antica e scienze affini 3: 75-102.

Charachidzé G (1988) Prometeo o il Caucaso (Prometheus or the Caucasus). Milan: Feltrinelli.

Chevalier J, Gheerbrant A (1986) Dizionario dei simboli (The Dictionary of Symbols). Milan: Rizzoli.

Chiesa Isnardi G (1991) I miti nordici (The Nordic Myths). Milan: Longanesi.

Cleasby R, Vigfusson G (1874) An Icelandic-English Dictionary. Oxford: Clarendon Press.

Comparetti D (1891) Il "Kalevala", o la poesia tradizionale dei Finni: studio storicocritico sulle origini delle grandi epopee nazionali (The "Kalevala", or the Traditional Poetry of the Finns: A Historical-Critical Study on the Origins of the Great National Epics). Rome: Tipografia della R. Accademia dei Lincei.

Cornford FM (1952) Principium Sapientiae. The Origins of Greek Philosophical Thought. Cambridge: Cambridge University Press.

Corradi Musi C (2004) Lo sciamanesimo ugrofinnico e la tradizione celtica (The Finno-Ugric Shamanism and the Celtic Tradition). Studi Celtici 3: 57-82.

Couliano IP (1991) Out of This World. Boston: Shambhala.

Crawley AE (1902) The Mystic Rose: A Study of Primitive Marriage. London: Macmillan.

Dana D (2010) Preuve et malentendu: Le mythe historiographique de l'origine et de la transmission du chamanisme en Grèce ancienne (Proof and Misunderstanding: The Historiographic Myth of the Origin and Transmission of Shamanism in Ancient Greece). Cahiers du Centre de Recherches Historiques 45: 109-128.

Dasent GW (1903) Popular Tales from the Norse. Edinburgh: Douglas.

de Anna LG (1988) Conoscenza e immagine della Finlandia e del Settentrione nella cultura classico-medievale (Knowledge and Image of Finland and the North in Classical-Medieval Culture). Turku: Turun Yliopisto.

de Anna LG (1996) La terra dei venditori di vento. La percezione della magia tempestaria boreale nella cultura occidentale (The Land of Wind-Sellers. The Perception of the Boreal Weather Magic in Western Culture). Avallon 40: 49-71.

de Anna LG (2001) Forme dello sciamanismo boreale (Forms of Boreal Shamanism). Avallon 49: 41-53.

de Anna LG (2003) Sesso lappone. La prostituzione d'ospitalità nei racconti dei viaggiatori (Lapp Sex. The Hospitable Prostitution According to the Travelers' Tales). Itineraria 2: 305-324.

Devereux G (1978) Saggi di etnopsichiatria generale (Essays of General Ethnopsychiatry). Rome: Armando.

Diels H (1922) Himmels-und Höllenfahrten von Homer bis Dante (Ascents to the Sky and Descents to the Hell from Homer to Dante). Neue Jahrbücher für klassische Altertum, Geschichte und deutsche Literatur und für Pädagogik 49(6-7): 239-253.

Dimock GB (1956) The Name of Odysseus. Hudson Review 9: 52-70.

Diószegi V (1952) Le combat sous forme d'animal des chamanes (The Shamanistic Combat in the Shape of Animals). Acta Orientalia Academiae Scientiarum Hungaricae 2(2-3): 303-316.

Dodds ER (1951) The Greeks and the Irrational. Berkeley, Los Angeles: University of California Press. 
Duichin M (1992) L'eroe claudicante. Ferite iniziatiche e viaggi nell'aldilà (The Limping Hero. Initiatiory Wounds and Journeys into the Beyond). Il Contributo 16(2): 3-26.

Duichin M (1996) Ieropornìa. Prostituzione rituale e sacrifici di fanciulle nella tradizione classica, nelle leggende e nei racconti di fiaba (Ieropornia. Ritual Prostitution and Maidens' Sacrifices in Classical Tradition, Legends, and Fairytales). Rome: Il mondo 3.

Duichin M (2003) Socrate tra filosofia e sciamanismo. Echi e motivi culturali anellenici nel pensiero greco del V sec. A.C. (Socrates between Philosophy and Shamanism. Un-Hellenic Echoes and Motifs in the Greek Thought of the $5^{\text {th }}$ Century B.C). Seminari Romani di Cultura Greca 6(2): 253-299.

Duichin M (2012) Odysseus' Scar: Traces of Boreal Shamanism in the Odyssey? In G Tripodi (Ed.), Iliad and Odyssey in Northern Europe. Proceedings of the $2^{\text {nd }}$ International Conference, Toija, Finland, July 23-24, 2011, 54-78. Messina: Samperi Editore.

Duichin M (2013) Il lato oscuro di Odisseo: eroe greco o "sciamano" nordico? (The Dark Side of Odysseus: Greek Hero or Nordic "Shaman"?). Rivista di Cultura Classica e Medioevale 55(2): 267-297.

Dumézil G (1970) The Destiny of the Warrior. Chicago, London: University of Chicago Press.

Dumézil G (2001) La saga di Hadingus. Dal mito al romanzo (From Myth to Fiction: The Saga of Hadingus). Rome: Edizioni Mediterranee.

Düntzer H (1874) Die homerischen Fragen (Homeric Questions). Leipzig: Hahn.

Eisler R (1951) Man into Wolf. An Anthropological Interpretation of Sadism, Masochism, and Lycanthropy. London: Routledge and Kegan.

Eliade M (1964) Shamanism: Archaic Techniques of Ecstasy. Princeton, Oxford: Princeton University Press.

Ellis HR (1968) The Road to Hel. A Study of the Conception of the Dead in Old Norse Literature. New York: Greenwood.

Fago A (1981) L'occidente "latino" di fronte al nord artico e ai lapponi (The "Latin" West Facing the Arctic North and the Lapps). In G Mazzoleni (Eds.), Same I- La dimensione remota (Same I- The Remote Dimension) (143-321). Rome: Bulzoni.

Ferrari A (1999) Dizionario di mitologia greca e latina (Dictionary of Greek and Latin Mythology). Turin: UTET.

Ferrari F (2002) Nel segno di Circe: la politropia di Odisseo (In the Sign of Kirke: Odysseus' Versatility). In A Hurst, F Létoublon (Eds.), La mythologie et l'Odyssée. Hommage à Gabriel Germain (Mythology and the Odyssey. Tribute to Gabriel Germain) (27-44). Genève: Droz.

Ferrari F (2003) Saga di Oddr l'arciere (13 ${ }^{\text {th }}$ cent.) (The Saga of Örvar Odd), edited by F Ferrari. Milan: Rizzoli.

Flaherty G (1992) Shamanism and the Eighteenth Century. Princeton, NJ: Princeton University Press.

Frazer J (1984) Il ramo d'oro. Studio sulla magia e la religione (The Golden Bough. A Study in Magic and Religion). Turin: Boringhieri.

Funk and Wagnalls (1984) Funk \& Wagnalls Standard Dictionary of Folklore, Mythology, and Legend, edited by M Leach, J Fried. San Francisco: Harper \& Row.

Galloni P (2008-2009) Escursioni sciamaniche (Shamanistic Excursions). Studi Celtici 7: $97-127$.

George-Kokkinaki M (2008) Literary Anthroponymy: Decoding the Characters of Homer's Odyssey. Antrocom 4(2): 145-157.

Gernet L (1981) Dolon the Wolf. In The Anthropology of Ancient Greece (125-139). Baltimore, MD: Johns Hopkins University Press. 
Gervasius von Tilbury (1856) Otia Imperialia $\left(13^{\text {th }}\right.$ cent.) (Recreation for an Emperor), edited by F Liebrecht. Hannover: Rümpler.

Ginzburg C (1989) Storia notturna. Una decifrazione del sabba (Ecstasies: Deciphering the Witches'Sabbath). Turin: Einaudi.

Ginzburg C (2006) Gli europei scoprono (o riscoprono) gli sciamani (The Europeans Discover [or Rediscover] the Shamans). In Il filo e le tracce. Vero, falso, finto (Threades and Traces. True, False, Fictive) (94-111). Milan: Feltrinelli.

Graf F (1987) Orpheus: A Poet Among Men. In J Bremmer (Ed.), Interpretations of Greek Mythology (80-106). London, Sydney: Croom Helm.

Grambo R (1973) Sleep as a Means of Ecstasy and Divination. Acta Ethnographica Academiae Scientiarum Hungaricae 22: 417-425.

Greene FG (1996) Homer's Odysseus as an Ecstatic Voyager. Journal of Near-Death Studies 14(4): 225-250.

Grimal P (1987) Dizionario di mitologia greca e romana (Dictionary of Greek and Roman Mythology). Brescia: Paideia.

Grimm J (1888) Teutonic Mythology: Vol. IV, edited by JS Stallybrass. London: George Bell \& Sons.

Grimm J and W (1980) Fiabe per i fanciulli e la famiglia (1812-1815) (Children's and Household Tales), edited by G Dolfini. Milan: Mondadori.

Guidorizzi G (2010) Ai confini dell'anima. I Greci e la follia (At the Soul's Boundaries. The Greeks and the Madness). Milan: Cortina.

Hadot P (2001) Shamanism and Greek Philosophy. In H-P Francfort, R-N Hamayon (Eds.), The Concept of Shamanism: Uses and Abuses (389-401). Budaperst: Akadémiai Kiadó.

Hahn von JG (1918) Griechische und albanesische Märchen (Greek and Albanian Fairytales): Vol. I. München-Berlin: Müller.

Hallowell A (1926) Bear Ceremonialism in the Northern Hemisphere. American Anthropologist 28(1): 1-175.

Haney JV (2015) An Introduction to the Russian Folktale. London, New York: Routledge.

Harsh PW (1950) Penelope and Odysseus in Odyssey XIX. American Journal of Philology 71(1): 1-21.

Hartland ES (1896) The Legend of Perseus. A Study on Tradition in Story, Custom, and Belief: Vol. III. London: Nutt.

Harva U (1959) Les représentations religieuses des peuples altaïques (The Religious Beliefs of the Altaic Peoples). Paris: Gallimard.

Hatto AT (1980) Shamanism and Epic Poetry in Northern Asia. In Essays on Medieval German and Other Poetry (117-140). Cambridge: Cambridge University Press.

Heubeck A (1974) Die homerische Frage (The Homeric Question). Darmstadt: Wissenschaftliche Buchgesellschaft.

Heubeck A (1981) Interpretazione dell'Odissea (Interpretation of the Odyssey). In H Heubeck, S West (Eds.), Omero, Odissea: Vol. I (IX-XXXVII). Milan: Fondazione Valla/Mondadori.

Hölscher U (1991) L'Odissea. Epos tra fiaba e romanzo (The Odyssey: Epos between Fairytale and Novel). Florence: Le Lettere.

Hultkrantz A (1992) Aspects of Saami (Lapp) Shamanism. In M Hoppál, J Pentikäinen (Eds.), Northern Religions and Shamanism (138-145). Budapest: Akadémiai Kiadó.

Hurst A (2002) L'Odyssée de Lycophron (The Odyssey of Lycophron). In A Hurst, F Létoublon (Eds.), La mythologie et l'Odyssée. Hommage à Gabriel Germain (Mythology and the Odyssey. Tribute to Gabriel Germain) (115-127). Genève: Droz.

Iliad (1951) The Iliad of Homer, translated by R Lattimore. Chicago: University of Chicago Press. 
Kalevala (1989) The Kalevala. An epic poem after oral tradition by E Lönnrot, edited by K Bosley. Oxford, New York: Oxford University Press.

Kamptz von H (1982) Homerische Personennamen. Sprachwissenschaftliche und historische Klassifikation (Homeric Person Names: A Linguistic and Historical Classification). Göttingen: Vandenhoeck \& Ruprecht.

Kanavou N (2015) The Names of Homeric Heroes: Problems and Interpretations. Berlin, Boston: de Gruyter.

Kerényi C (1980) Gli dei e gli eroi della Grecia (The Gods and Heroes of the Greeks): Vols. I-II. Milan: il Saggiatore.

Kingsley P (1994) Greeks, Shamans and Magi. Studia Iranica 23: 187-198.

Kirkinen H, Sihvo H (2007) The Kalevala. An Epic of Finland and All Mankind. Helsinki: The League of Finnish-American Societies.

Jochelson WJ (1908) The Koriak. New York: Memories of the American Museum of Natural History.

Latacz J (1990) Omero. Il primo poeta dell'Occidente (Homer: The First Poet of the West). Rome, Bari: Laterza.

Lecouteux C (2005) Dietro alla metamorfosi (Behind the Metamorphosis). In S Bosco Coletsos, M Costa (Eds.), Fiaba, Märchen, Conte, Fairy Tale. Variazioni sul tema della metamorfosi (Fiaba, Märchen, Conte, Fairytale: Variations on the Theme of Metamorphosis) (13-25). Turin: Centro Scientifico Editore.

Lesky A (1984) Storia della letteratura greca (History of Greek Literature): Vol. I. Milan: il Saggiatore.

LSJ (1969) A Greek-English Lexicon. Compiled by HG Liddell and R Scott, revised and augmented throughout by HS Jones, with the assistance of R McKenzie. With a revised supplement. Oxford: Clarendon Press.

LIMC (1981-1999) Lexicon iconographicum mythologiae classicae: Vol. I. Zürich, München, Düsseldorf: Artemis \& Winkler Verlag.

Lincoln MB (1975) Homeric lýssa: "Wolfish Rage". Indogermanische Forschungen 80: 98-105.

Lindsay J (1965) The Clashing Rocks: A Study of Early Greek Religion and Culture and the Origins of Drama. London: Chapman \& Hall.

Lord AB (1965) Beowulf and Odysseus. In JB Bessinger, RP Creed (Eds.), Franciplegius: Medieval and Linguistic Studies in Honor of F.P. Magoun jr (86-91). New York: New York University Press.

Loscalzo D (2012) Odysseus, an Abnormal Hero. In G Tripodi (Ed.), Iliad and Odyssey in Northern Europe. Proceedings of the $2^{\text {nd }}$ International Conference, Toija, Finland, July 23-24, 2011, 126-136. Messina: Samperi Editore.

Lubbock J (1879) The Origin of Civilization and the Primitive Condition of Man. New York: Appleton and Co.

MacCulloch JA (1905) The Childhood of Fiction: A Study of Folk Tales and Primitive Thought. New York: Dutton and Co.

Marazzi U (1984) Testi dello sciamanesimo siberiano e centroasiatico (Texts of Siberian and Central Asian Shamanism), edited by U Marazzi. Turin: UTET.

Martinotti G, Chillemi E (2013) L'Odissea: ovvero la raccolta di icaros sciamanici in trance estasica (The Odyssey: Or the Collection of Shamanic Icaros in Ecstatic Trance). Rivista di Cultura Classica e Medioevale 55(2): 299-318.

Mastromattei R (1988) La freccia di Odysseus (The Arrow of Odysseus). Quaderni Urbinati di Cultura Classica 29(2): 7-22.

Meli M (1997) Antiche saghe nordiche (Old Nordic Sagas), edited by M Meli: Vol. I. Milan: Mondadori.

Meriggi B (1974) Le Byline. Canti popolari russi (The Byliny. Russian Oral Epic Poems). Milan: Edizioni Accademia. 
Metzler D (1982) Zum Schamanismus in Griechenland (On Shamanism in Greece). In C Müller-Wirth, B Otto, D Metzler (Eds.), Antidoron. Festschrift für Jürgen Thimme (Antidoron: Commemorative Essays for Jürgen Thimme) (75-82). Karlsruhe: Müller.

Meuli K (1921) Odyssee und Argonautika. Untersuchungen zur griechischen Sagengeschichten und zum Epos (Odyssey and Argonautica: Studies on the History of Greek Legends and Epos). Berlin: Weidmann.

Meuli K (1935) Scythica. Hermes 70: 121-176.

Muster W (1947) Der Schamanismus und seine Spuren in der Saga, im deutschen Brauch, Märchen und Glauben (Shamanism: Its Traces in the Saga, German Custom, Fairytales, and Beliefs) (PhD Dissertation). Karl Franzens Universität, Graz, Austria.

Negri F (1700) Viaggio Settentrionale. Fatto, e Descritto dal molto Rever. Sig. D. Francesco Negri da Ravenna. Opera postuma (Northern Journey. Done, and Described by the Very Reverend Mr. D. Francesco Negri from Ravenna. Posthumous Work). Padua: Stamperia del Seminario. Anastatic reprint. Bergamo: Leading Edizioni.

Nortwick van T (2009) The Unknown Odysseus: Alternate Worlds in Homer's Odyssey. Ann Arbor, MI: University of Michigan Press.

Odyssey (1968) The Odyssey of Homer, translated by R Lattimore. New York: Harper \& Row.

Ogden D (2004) Greek and Roman Necromancy. Princeton, Oxford: Princeton University Press.

Oitana L (2005) La metamorfosi iniziatica nella letteratura norrena: i casi della Völsunga saga e della Hrólfs saga kraka (The Initiatory Metamorphosis in Norse Literature: The Cases of the Völsunga saga and the Hrólfs saga kraka). In S Bosco Coletsos, M Costa (Eds.), Fiaba, Märchen, Conte, Fairy Tale. Variazioni sul tema della metamorfosi (Fiaba, Märchen, Conte, Fairytale. Variations on the Theme of Metamorphosis) (260-271). Turin: Centro Scientifico Editore.

Olaus Magnus (1555) Historia de gentibus septentrionalibus (A Description of the Northern Peoples). Rome MDLV.

Page D (1983) Racconti popolari nell'Odissea (Folktales in Homer's Odyssey). Neaples: Liguori.

Panzer F (1910) Studien zur germanischen Sagengeschichte. I. Beowulf (Studies on the History of German Legends. I. Beowulf). München: Beck.

Pekkanen T (1983) The Hellusii and the Oxiones of Tac. Germ. 46, 4. Arctos 17: 49-60.

Pentikäinen JY (1999) Kalevala Mythology. Expanded edition. Bloomington, Indianapolis: Indiana University Press.

Pentikäinen JY (2007a) Golden King of the Forest. The Lore of the Northern Bear. Helsinki: Etnika Oy.

Pentikäinen JY (2007b) Gli sciamani e lo sciamanesimo siberiano (Shamans and Siberian Shamanism). In VM Piludu (Ed.), Sulle tracce della renna del cielo. Scritti sullo sciamanesimo nordico (Following the Tracks of the Heaven's Reindeer. Essays on Nordic Shamanism) (27-44). Rome: Bulzoni.

Ploss HH, Bartels M, Bartels P (1935) Woman. An Historical, Gyncecological and Anthropological Compendium: Vol. II. London: Heinemann.

Pokorny J (1959) Indogermanisches Etymologisches Wörterbuch (Indo-European Etymological Dictionary): Vol. I. Bern, München: Francke Verlag.

Propp VJ (1978) L'epos eroico russo (Russian Heroic Epos). Rome: Newton Compton.

Przyluski J (1940) Les confréries de loups-garous dans les sociétés indo-européennes (Werewolf-Fraternities in the Indo-European Societies). Revue de l'Histoire des Religions 121: 128-145.

Qvigstad JK (1927) Lappiske eventyr og sagn (Lappish Stories and Legends): Vol. III/1. Oslo: Instituttet for sammenlignende kulturforskning. 
RE (1894-1980) Paulys Realencyclopädie der classischen Altertumswissenschaft (Pauly's Realcyclopedia of Classical Antiquity), edited by A Pauly, G Wissowa, W Kroll et al. Stuttgart: Metzler.

Renaud J-M, Wathelet P (2002) L'initiation de Télémaque dans l'Odyssée (Telemachos' Initiation in the Odyssey). In A Hurst, F Létoublon (Eds.), La mythologie et l'Odyssée. Hommage à Gabriel Germain (Mythology and the Odyssey. Tribute to Gabriel Germain) (273-286). Genève: Droz.

Roscher WH (1896) Das von der "Kynanthropie" handelnde Fragment des Marcellus von Side (The Fragment on the "Cynanthropy" by Marcellus of Side). Abhandlungen der philologischen-historischen Classen der Königlich Sächsischen Gesellschaft der Wissenschaften 17(3): 3-86.

Rose HJ (1964) A Handbook of Greek Mythology. London: Methuen \& Co.

Roux J-P (1961) Le chaman altaïque d'après les voyageurs européens des XVII ${ }^{\mathrm{e}}$ et XVIII ${ }^{\mathrm{e}}$ siècles (The Altaic Shaman according to the European Travelers of the $17^{\mathrm{h}}$ and $18^{\text {th }}$ centuries). Anthropos 5: 438-458.

Roux J-P (1966) Le chaman (The Shaman). In Le monde du sorcier (The World of the Sorcerer) (205-232). Paris: Editions du Seuil.

Roux J-P (1990) La religione dei Turchi e dei Mongoli (The Religion of the Turks and Mongols). Genoa: ECIG.

Rozokoki A (2001) Penelope's Dream in Book 19 of "Odyssey". Classical Quarterly 51(1): 1-16.

Sargent B (2002) Les Phéaciens avant l'Odyssée (The Phaeacians before the Odyssey). In A Hurst, F Létoublon (Eds.), La mythologie et l'Odyssée. Hommage à Gabriel Germain (Mythology and the Odyssey. Tribute to Gabriel Germain) (199-219). Genève: Droz.

Saronne ET (1988) Il cantare di Igor' (12 ${ }^{\text {th }}$ cent.) (The Poem of Igor'), edited by ET Saronne. Parma: Pratiche Editrice.

Saronne ET, Danil'čenko KF (1997) Giganti, incantatori e draghi. Byline dell'antica Rus' (Giants, Sorcerers, and Dragons: The Byliny of Ancient Rus'), edited by ET Saronne, KF Danil'čenko. Milan-Trento: Luni.

Saxo Grammaticus (1993) Gesta dei re e degli eroi danesi $\left(12^{\text {th }}\right.$ cent.) (The History of the Danes), edited by L Koch, MA Cipolla. Turin: Einaudi.

Schefferus J (1673) Lapponia (Lapland). Francofurti: Ch. Wolfii.

Schrader O (1912) Die Indogermanen (The Indo-Europeans). Leipzig: Quelle \& Mayer.

Schwartz E (1924) Die Odyssee (The Odyssey). München: Hueler.

Siikala A-L (1986) Shamanistic Themes in Finnish Epic Poetry. In I Lehtinen (Eds.), Traces of Central Asian Culture in the North (223-233). Helsinki: Mémoires de la Société Finno-Ougrienne.

Siikala A-L (1999) Suomalainen šamanismi (Finnish Shamanism). Helsinki: Suomalaisen Kirjallisuuden Seura.

Siikala A-L (2007) I tietäjä finnici e lo sciamanesimo (The Finnish Tietäjä and Shamanism). In VM Piludu (Ed.), Sulle tracce della renna del cielo. Scritti sullo sciamanesimo nordico (Following the Tracks of the Heaven's Reindeer: Essays on Nordic Shamanism) (101-152). Rome: Bulzoni.

Stanford WB (1952) The Homeric Etymology of the Name Odysseus. Classical Philology 47(4): 209-213.

Stanford WB (1954) The Ulysses Theme. A Study in the Adaptability of a Traditional Hero. Oxford: Blackwell.

Stitt JM (1992) Beowulf and the Bear's Son: Epic, Saga and Fairytales in Northern Germanic Tradition. New York: Garland.

Stutley M (2003) Shamanism: An Introduction. London, New York: Routledge.

Summers M (1933) The Werewolf. London: Kegan, Trench, Trubner \& Co. 
Tasso T (1958) Il Messaggiero (1587) (The Messenger). In E Raimondi (Eds.), Dialoghi (Dialogues) Vol. II (249-332). Florence: Sansoni.

Thompson S (= TMI) (1955-1958) Motif-Index of Folk Literature. Bloomington, Indianapolis: Indiana University Press.

Thompson S (1979) La fiaba nella tradizione popolare (The Folktale). Milan: il Saggiatore.

Thorburn JE (2005) The Facts on File Companion to Classical Drama. New York: Facts On File.

Thornton A (1970) People and Themes in Homer's Odyssey. London: Methuen \& Co.

Tolley C (1994) The Shamanic Séance in the Historia Norvegiae. Shaman. Journal of International Society for Shamanistic Research 2: 115-136.

Turi J (1991) Vita del lappone (An Account of the Sámi). Milan: Adelphi.

Vernadsky G (1965) Le origini della Russia (The Origins of Russia). Florence: Sansoni.

Vinci F (2008) ${ }^{5}$ Omero nel Baltico. Le origini nordiche dell'Odissea e dell'lliade (The Baltic Origins of Homer's Epic Tales). Rome, Palombi.

Vitebsky P (2001) Shamanism. Norman, OK.: University of Oklahoma Press.

Waida M (1983) Problems of Central Asian and Siberian Shamanism. Numen 39(2): 215239.

Weber M (1923) Wirtschaftsgeschichte (General Economic History). München, Leipzig: Duncker \& Humblot.

Weicker G (1902) Der Seelenvogel in der alten Literatur und Kunst. Eine mythologischearchäologische Untersuchung (The Soul-Bird in Ancient Literature and Art: A Mythological-Archaeological Investigation). Leipzig: Meiner.

Westermarck E (1891) The History of Human Marriage. London, New York: Macmillan.

Wilamowitz-Moellendorf U (1927) Die Heimkehr des Odysseus (The Return of Odysseus). Berlin: Weidmann.

Whittaker H (1999) The Status of Arete in the Phaeacian Episode in Homer's Odyssey. Symbolae Osloenses 74(1): 140-150.

Woodhouse WJ (1930) The Composition of Homer's Odyssey. Oxford: Clarendon Press. 
